this notion to the U.S., most noticeably in "Bowling Alone." These seminal analyses directly and explicitly build on Banfield's work on political culture.

Like Banfield, Putnam asks, "Where and why does Tocqueville's analysis work?" "Does local participation really generate democratic local leadership, shared values, and trust among citizens?" "What happens if you do have a New Englandstyle Tocquevillian legacy, but then participation drops?" And the debate is on. At the last meeting of the American Political Science Association, these issues were among the most actively discussed. The same topics have engaged European and Japanese political scientists.

These are hard issues that Banfield started us thinking about. They continue a University of Chicago tradition. Banfield trained there with Edward Shils. Shils translated Max Weber and created this tradition of political cultural analysis in America, passing it on to his students Edward Banficld, Gabriel Almond, Daniel Elazar, Ronald Inglehart, and others who, through their students and followers, have helped make these core concerns in our lives today.

Terry Nichols Clark University of Chicago

\section{Harry H. Eckstein}

Harry Eckstein, Distinguished Research Professor in the department of political science of the University of California, Irvine, died on June 22,1999 , of heart failure. He was one of the most prominent and respected social scientists of the second half of the twentieth century. The sweep of Eckstein's intellect and the depth of his learning were all but unique in a discipline that has experienced increasing specialization. His reputation is based, in part, on sustained, cumulative, innovative use of culture as an organizing concept for the rigorous study of politics, which revealed the bases of effective (stable) democracy and the nature of authority, and, in part, on the unusual trait of having made important, at times seminal, contributions to a host of diverse subfields of political inquiry. Moreover, he will be remembered for his critically important work on the political systems of Britain, Norway, and, in recent years, democratizing post-Soviet Russia.

Harry Eckstein was born on January 26, 1924, in Schotten, Germany. His family suffered the horror and dislocations of the Holocaust. In 1936, at the age of 12, Eckstein left for the U.S., as part of a group of 500 German youths selected for immigration on the basis of intelligence tests administered by American authorities. Although his sister, Ilsa, later escaped Germany and eventually settled in the U.S., the rest of his family perished in concentration camps. Eckstein spent his adolescent years in Columbus, Ohio.

Recognized as a brilliant student, Eckstein was awarded a scholarship to Harvard University, where he earned his bachelor of arts (1948, summa cum laude), masters (1950), and doctoral (1953) degrees in political science. World War II interrupted his undergraduate training, and he served a stint in the Pacific theater. His doctoral dissertation was published as The English Health Service (Harvard University Press and Oxford University Press, 1958). It was quickly followed by his study of the British Medical Association, Pressure Group Politics (Stanford University Press, 1958), which helped focus the field and remains one of the best examples of interest group analyses to this day.

Eckstein's Internal War (Free Press, 1964) was a truly pioneering study that drew attention to the need for (and thereby stimulated) systematic study of civil strife and revolution. Later, in a frequently reprinted 1965 article titled "On the Etiology of Internal Wars" (History and Theory 4[2]), he clearly disentangled what had been total confusion between the "preconditions" and the "precipitants" of civil strife.

In addition to substantive and theoretical contributions, epitomized by the work on the English national health service, interest groups, and internal war, Eckstein made important contributions to the methodology of comparative politics. His "Case Study and Theory in Political Science" (in Greenstein and Polsby's
1973 Handbook of Political Science) demonstrates the special utility of "crucial case studies" for testing theory, undermining the accepted wisdom in comparative research that more cases yielded better results.

By itself, the research described so far comprises a corpus of work important enough to both explain and justify Eckstein's international reputation. However, his central contribution to political science was his development of a framework for explaining effective democratic government and analyzing the nature of authority relations. His classic monograph, $A$ Theory of Stable Democracy (Princeton, 1961) sketches out the basic tenets of "congruence theory," which has become one of the most important tools for understanding democratic rule. Put in an overly simple way, the essential idea is that a country in which parentchild, teacher-student, and employeremployee relations are authoritarian cannot establish durable democratic government; developing such a regime requires establishing and fostering social authority relations which increasingly resemble democratic relationships as one moves from social units quite distant from the government (e.g., the family and primary school) to ones which are close (e.g., work organizations, voluntary associations, and political parties).

The monograph develops this basic idea and shows that it fits most extensively studied democracies. Next, Eckstein researched and published Division and Cohesion in Democracy (Princeton University Press, 1966), a case study of Norway which served as a plausibility probe for congruence theory.

On this foundation, Eckstein built his work on authority, which soon developed into a major independent endeavor. Many scholars had suggested that a rigorous, scientific study of politics could not be confined to the sphere of government, that the discipline would have to focus on an eminently political phenomenon such as influence, power or authority. Eckstein, uniquely among those who issued it, heeded this call and produced an important body of scholarship arguing that po- 
litical scientists should study the nature of authority and, with Ted Gurr, a majesterial (although largely ignored so far) work implementing the idea: Patterns of Authority (Wiley, 1975).

His authority research resulted in a number of essays on political culture, including "A Culturist Theory of Political Change" (APSR, 1988), and social science as a "cultural science." In 1998, he edited and contributed chapters to Can Democracy Take Root in Post-Soviet Russia?

(Rowman and Littlefield), and published an article in Comparative Political Studies on the nature and scope of comparative politics.

Harry Eckstein began his teaching career in the government department at Harvard where he served as an instructor and an assistant professor (1954-58). He moved to Princeton in 1959 as an associate professor and was named the IBM Professor of International Studies in 1969. In 1980, he moved to the School of Social Sciences at the UCIrvine, where he was UCI's first Distinguished Professor.

Professor Eckstein continued to be an active scholar and colleague until the eve of his death. He was an energetic participant in university life at Irvine, where he served as founding chair of the department of politics and society, helped to establish the UCI Center for the Study of Democracy in 1995, and organized many of the Center's activities in recent years. Barely a week before he passed away, Eckstein completed teaching his last course, on political culture. His loss will be felt by the many graduate students he was still supervising, the undergraduates with whom he met regularly in his office, and by his many colleagues at Irvine and around the world who relied on him for wisdom and counsel.

Harry Eckstein was a fellow of the American Academy of Arts and Sciences (1970-99), fellow of the Center for Advanced Study in the Behavioral Sciences at Stanford (195859), Guggenheim fellow (1974), American Political Science Association Annual Meeting program chair (1966-67), APSA vice president (1981-82), editor (1960-63) and member of the editorial board of
World Politics (1960-80), a founding member of the editorial board of Comparative Political Studies (196699), the IBM Professor of International Studies at Princeton University (1969-80), and, finally, Distinguished Professor (1980-93) and Distinguished Research Professor (1993-99) of Political Science at UC-Irvine.

Many of Professor Eckstein's writings are standards of political science and required reading for students. In 1992, a number of his important articles were compiled and published as Regarding Politics (University of California Press). He wrote and edited nine other books. In August 1998, Comparative Political Studies published "A Tribute to Harry Eckstein." No other American political scientist has been honored by a political science journal in this way.

Harry Eckstein was a passionate, serious man. He loved music deeply and played the violin and viola nearly all of his life, often in string quartets made up of friends and colleagues. He followed international soccer and cricket avidly. In recent years, he could be found surfing the net to keep abreast of recent friendlies and test matches. He was an excellent poker player, a game that he mastered in the Army, and he won far more than he lost. Eckstein's conversation, perhaps the most endearing feature of his personality, was always serious and erudite. He seemed to be interested in, and to know an astonishing amount about, any topic that might be raised. He was a deeply committed scholar and a true gentleman who treated all members of the community, from the most accomplished of scholars to struggling undergraduates and members of the staff, with kindness, sincerity, and courtesy.

William R. Schonfield University of California, Irvine Alec Stone Sweet University of California, Irvine

\section{Daniel J. Elazar}

Daniel Judah Elazar, 65, beloved teacher and pioneering scholar, and internationally renowned student of federalism, passed away on Decem- ber 2, 1999, at his home in Jerusalem. Friends are planning a memorial at the 2000 APSA meeting.

In August, Dan had been diagnosed with lymphoma in Philadelphia after directing a summer institute on American constitutionalism for international scholars in Colorado under the auspices of the U.S. Information Agency. Being in the Mountain West was always a joy for Dan. The majestic Rockies symbolized for him both the strengths of America and the challenges of what he saw as America's continuing frontier experience. He returned to Jerusalem to be with his family and in the city that lay at the heart of his work and spirit. Jerusalem and the Rockies very much defined the poles of Dan's own "geohistorical location," a term he developed during his studies of America's cities of the prairie, while Philadelphia, birthplace of the Declaration of Independence and the United States Constitution, symbolized the fertile ground of liberty Americans had come to cultivate between those poles. Dan was immensely sentimental about such matters, and he was a man for whom such symbols were real and important.

Dan is survived by his wife, Harriet; three children, Naomi, Yonatan, and Gideon; three grandchildren; and his brother, David. Dan's principal institutional legacies include the Center for the Study of Federalism and Center for Jewish Community Studies at Temple University, Philadelphia; the Jerusalem Center for Public Affairs in Israel; the International Association of Centers for Federal Studies, of which he was the founding president; and Publius: The Journal of Federalism and Jewish Political Studies Review. Among other activities, he served as a council member and as secretary of the American Political Science Association, chairman of the Israel Political Science Association, a citizen member of the U.S. Advisory Commission on Intergovernmental Relations for three terms, a member of many consultative bodies for the government of Israel, and as an advisor or consultant for the U.S. Senate Subcommittee on Intergovernmental Relations, Education 